\title{
PERBANDINGAN UNJUK KERJA TRANSMISI JARINGAN FTTB MENGGUNAKAN GEPON DAN GPON
}

\section{PERFORMANCE COMPARISON OF TRANSMISSION FTTB NETWORK USING GEPON AND GPON}

\author{
Tri Nopiani Damayanti ${ }^{1}$, Hasanah Putri ${ }^{2}$ \\ ${ }^{1,2}$ Fakultas Ilmu Terapan, Universitas Telkom \\ $\underline{{ }^{1} \text { damayanti@tass.telkomuniveristy.ac.id }},{ }^{2}$ hasanahputri@tass.telkomuniversity.ac.id
}

\begin{abstract}
Abstrak
Penelitian ini dilakukan untuk menganalisa perbandingan unjuk kerja transmisi teknologi GEPON dan GPON pada jaringan Fiber to the Building (FTTB). Pembahasan perbandingan menggunakan kedua teknologi PON tersebut untuk melihat performansi yang terbaik untuk di aplikasikan pada gedung bertingkat $\mathrm{X}$ menggunakan passive splitter dua tingkat dengan rasio perbandingan passive splitter maksimum 1:16. Unjuk kerja transmisi disimulasikan berdasarkan parameter link power budget, rise time budget serta nilai Bit Error Rate (BER) untuk kelayakan sistem jaringan. Perhitungan Unjuk jaringan dibagi menjadi bagian yaitu arah downstream dan arah upstream. Hasil perhitungan didapatkan pada arah downstream jarak terjauh, link GEPON menghasilkan nilai redaman sebesar $22.81 \mathrm{~dB}$, BER sebesar $7 \times 10^{-29}$ dan nilai rise time sebesar 0,2506 ns. Pada link GPON memiliki redaman sebesar $25.94 \mathrm{~dB}$, BER sebesar $3.62955 \times 10^{-12}$ dan nilai rise time sebesar 0.25 ns. Pada arah upstream jarak terjauh, link GEPON menghasilkan nilai redaman sebesar 4.65 $\mathrm{dB}$, dengan nilai $\mathrm{BER} \approx 0$, dan nilai rise time sebesar,2061 ns. Pada GPON memiliki redaman sebesar $4.65 \mathrm{~dB}, \mathrm{BER} \approx 0$ dan nilai rise time sebesar $0,260 \mathrm{~ns}$. Berdasarkan hasil unjuk kinerja kedua teknologi tersebut dapat disimpulkan bahwa unjuk kinerja teknologi GPON lebih baik dibandingkan teknologi GEPON untuk aplikasikan di jaringan optik gedung bertingkat.
\end{abstract}

\section{Kata kunci : FTTB, GEPON, GPON, Passive Splitter, OLT, BER}

\begin{abstract}
In this paper, we discuss the comparative analysis of the performance of the network transmission performance Fiber to the Building (FTTB) technology using GEPON and GPON. The design uses passive splitter two stages with a ratio maximum passive splitter is 1:16. FTTB network transmission performance with GEPON and GPON technology is simulated based on the parameters of link power budget, rise time budget and Bit Error Rate (BER). Performance calculations are divided into two directions downstreams and upstream. For downstream GEPON link, the total attenuation that is produced for the farthest distance is $22.81 \mathrm{~dB}$, BER is $7 \mathrm{x} 10-29$ and rise time is $0,2506 \mathrm{~ns}$. In GPON link the total attenuation that is produced for the farthest distance is $25.94 \mathrm{~dB}$, BER is $3.62955 \times 10-12$ and rise time is $0.25 \mathrm{~ns}$. For upstream GEPON link, the total attenuation for the farthest distance is $4.65 \mathrm{~dB}, \mathrm{BER}$ is $\approx 0$ and rise time is $0,2061 \mathrm{~ns}$. In GPON link the total attenuation for the farthest distance is $4.65 \mathrm{~dB}, \mathrm{BER}$ is $\approx 0$ and rise time is $0.260 \mathrm{~ns}$.
\end{abstract}

Keywords : FTTB, GEPON, GPON, Passive Splitter, OLT, BER 


\section{PENDAHULUAN}

Kebutuhan jaringan komunikasi yang memiliki kapasitas besar saat ini sangat penting. Hal ini untuk memenuhi kebutuhan masyarakat akan layanan informasi yang memiliki kecepatan dalam mentransfer data. Kebutuhan akan layanan ini dapat dipenuhi salah satunya menggunakan jaringan teknologi optik. Perkembangan teknologi optik yang memiliki bandwidth lebar, biaya rendah dengan konsumsi daya yang kecil banyak menarik minat para operator telekomunikasi untuk menggunakan teknologi optik dalam pembangunan jaringan telekomunikasi terutama untuk mendukung komunikasi layanan broadband. Salah satu teknologi jaringan optik yang menjanjikan dapat mendukung layanan broadband saat ini yaitu teknologi Passive Optical Network (PON) [1].

Teknologi Passive Optical Network (PON) merupakan teknologi pada jaringan optik point to multipoint (PTMP) pada jaringan FTTx yang menggunakan splitter pasif di bagian outside plant (OSP). Penggunaan teknologi PON dalam jaringan akses optik memiliki banyak keuntungan antara lain memiliki biaya yang murah dalam instalasi dan maintenance, mengurangi penggunaan banyak kabel optik, memiliki cakupan area yang luas dan mendukung aplikasi layanan broadband [2]. Teknologi PON menggunakan teknik multiple access TDM (Time Division Multiplexing) dengan dua standar yang digunakan yaitu GEPON dan GPON. Teknologi Gigabit Ethernet Passive Optical Network (GEPON) menggunakan standar IEEE 802.3ah EFM dengan laju maksimum 1.25 Gbps (laju data efektif $1.0 \mathrm{Gbps}$ ) untuk trafik downstream dan upstream. Teknologi PON lainnya yaitu Teknologi Gigabit Passive Optical Network GPON dengan standarisasi ITU-T G.984. Teknologi GPON memiliki kecepatan transmisi sebesar 1.244 Gbps untuk upstream dan 2.488 Gbps untuk downstream dengan cakupan area sepanjang $37 \mathrm{~km}$. Konfigurasi teknologi jaringan Passive Optical Network (PON) dideskripsikan pada gambar dibawah ini :

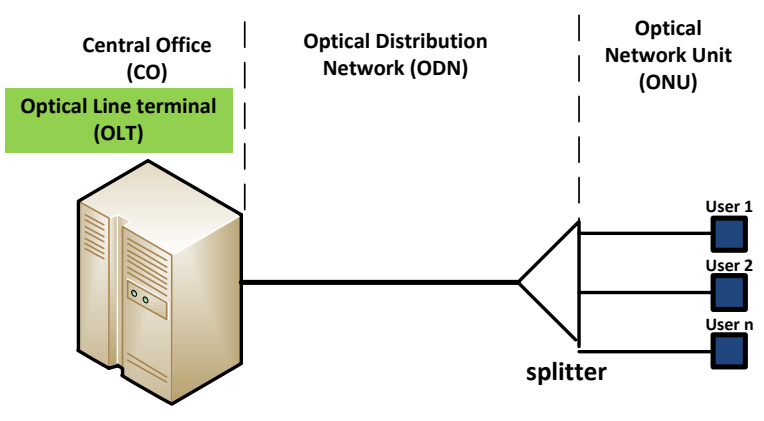

Gambar 1. Arsitektur PON Point to Multipoint [3]

Rajneesh Kaler, Pradeep Teotia, R.S. Kaler telah melaporkan hasil penelitiannya tentang jaringan FTTH menggunakan teknologi GEPON dengan layanan triple play. Penelitiannya melaporkan bahwa kebutuhan jaringan akses GEPON perlu mempertimbangkan kebutuhan layanan dan nilai BER dalam merancang jaringan akses FTTH [4]. Deeksha Kocher, R.S. Kaler, Rajneesh Randhaw juga telah melaporkan hasil dari penelitiannya menggunakan teknologi GEPON pada jaringan Fiber to the Home (FTTH) dan mendapatkan nilai BER $4.5246 .10^{-9}$ untuk 56 user dengan bit rate 2 Gbps dengan jarak jangkauan sebesar $20 \mathrm{~km}[5]$.

Penelitian tentang teknologi GPON oleh Sumanpreet, Dewra Sanjeev melaporkan hasil performansi dari penggunaan teknologi GPON pada jaringan FTTH dengan kecepatan transmisi downstream sebesar 2Gbps untuk 64 user didapatkan nilai BER sebesar 1.8.10 ${ }^{-10}$, Q faktor sebesar 6.2 dengan jangkauan maksimum sebesar $21 \mathrm{~km}$ [6].

Teknologi GEPON dan GPON yang telah dipaparkan pada penelitian tersebut di rancang untuk jaringan akses broadband untuk layanan triple play di area perumahan. Teknologi PON 
selain dapat digunakan untuk area perumahan dengan jaringan FTTH, teknologi PON juga dapat diaplikasikan untuk gedung bertingkat dengan jaringan Fiber to The Building (FTTB). Penelitian PON yang diaplikasikan pada FTTB telah dipaparkan oleh Pawel Parol, Michal Pawlowski dengan mensimulasikan jaringan FTTB menggunakan GPON dengan penambahan ethernet LAN. Hasil dari perancangan tersebut didapatkan nilai rasio paket loss sebesar 8.61.10 ${ }^{-6}$ [7]. Berdasarkan paparan diatas, penelitian ini akan membandingkan hasil performansi dari teknologi GEPON dan GPON yang diimplementasikan pada jaringan FTTB menggunakan passive splitter dua tingkat guna mendukung layanan triple play (Internet \& VoIP \& IPTV).

\section{DASAR TEORI}

\subsection{Fiber To The Building (FTTB)}

Fiber to The Building (FTTB) merupakan aplikasi teknologi jaringan akses optik FTTx yang menggunakan teknologi PON dengan layanan broadband triple play (Internet \& VoIP \& IPTv). Jaringan FTTB diaplikasikan pada suatu gedung baik berupa apartement, hotel, dan perkantoran. Suatu titik konversi optik (TKO) terletak didalam gedung dan biasanya terletak pada ruang di basement atau tersebar di beberapa lantai, terminal pelanggan dihubungkan dengan titik konversi optik (TKO), seperti di basement kemudian didistribusikan ke ruangan-ruangan yang dilakukan melalui beberapa alternatif konfigurasi.

\subsection{Gigabit Ethernet Passive Optical Network (GEPON) [8,9]}

Teknologi GEPON yang telah distandarisasi oleh IEEE 802.3ah EFM untuk satu perangkat OLT dapat menghubungkan maksimal untuk 32 ONU. Bandwidth maksimal pada masing masing ONU sebesar 1 Gbps untuk arah transmisi uplink dan downlink. Sistem WDM (Wavelength Division Multiplex) digunakan di transceiver optik GEPON dengan panjang gelombang yang berbeda untuk arah upstream dan downstream. Pada arah upstream panjang gelombang yang digunakan sebesar $1260 \mathrm{~nm}-1360 \mathrm{~nm}$ sedangkan untuk downstream menggunakan panjang gelombang sebesar $1480 \mathrm{~nm}-1500 \mathrm{~nm}$.

Pada arah transmisi downstream, GEPON bertindak sebagai shared medium, dengan frame-frame yang dikirim oleh OLT mencapai setiap ONU dengan arsitektur P2MP. Pada arah upstream, setiap ONU akan membagi bandwidth menggunakan teknik TDMA (Time Division Multiple Access). Tabel 1 berikut ini merupakan standar dari GEPON menurut IEEE 802.3 ah:

Tabel 1. Spesifikasi GEPON

\begin{tabular}{|l|l|}
\hline Standar & IEEE 802.3 ah \\
\hline Kecepatan(upstream/downstream) & 1.25 Gbps Simetris \\
\hline Layanan & Data, Suara, Video \\
\hline Perbandingan Splitter Maksimum & $1: 32$ \\
\hline Jarak Maksimum & $20 \mathrm{~km}$ \\
\hline Panjang Gelombang Downstream & $1490 \mathrm{~nm}$ \\
\hline Panjang Gelombang Upstream & $1310 \mathrm{~nm}$ \\
\hline Splitter & Pasif \\
\hline
\end{tabular}

\subsection{Gigabit Passive Optical Network (GPON) [10,11]}

Teknologi GPON menggunakan standar ITU.G.984, teknologi ini merupakan teknologi dengan jaringan point-to-multipoint dengan bit rate yang tinggi. Teknologi GPON menggunakan teknik multiple access TDMA dimana untuk kecepatan upstream sebesar 1.2 Gbps pada panjang 
gelombang $1310 \mathrm{~nm}$. Pada arah downstream kecepatan data sebesar 2.5 Gbps di panjang gelombang $1490 \mathrm{~nm}$ dan $1550 \mathrm{~nm}$. Spesifikasi GPON ditunjukkan tabel 2 berikut ini :

Tabel 2. Spesifikasi GPON

\begin{tabular}{|l|l|}
\hline Standar & ITU.G.984 \\
\hline Kecepatan downstream & $2.4 \mathrm{Gbps}$ \\
\hline Kecepatan Upstream & $1.2 \mathrm{Gbps}$ \\
\hline Layanan & Data, Suara, Video \\
\hline Perbandingan Splitter Maksimum & $1: 64$ \\
\hline Jarak Maksimum & $60 \mathrm{~km}$ \\
\hline Panjang Gelombang Downstream & $1490 \mathrm{~nm}$ dan $1550 \mathrm{~nm}$ \\
\hline Panjang Gelombang Upstream & $1310 \mathrm{~nm}$ \\
\hline Splitter & Pasif \\
\hline
\end{tabular}

\subsection{Optical Line Terminal (OLT)}

Perangkat OLT merupakan perangkat FTTx yang memiliki fungsi mengubah sinyal listrik menjadi sinyal optik. Perangkat ini sebagai antarmuka dari teknologi PON yang digunakan kearah ONT. OLT dihubungkan menggunakan kabel optik dan passive splitter menuju ONT/ONU.Pengaturan manajemen sistem dari perangkat OLT dilakukan oleh elemen managemen sistem (EMS).

\subsection{Optical Distribution Network (ODN)}

Perangkat ODN merupakan perangkat penyedia sarana transmisi optik ke perangkat ONU/ONT. Elemen perangkat ODN terdiri dari kabel optik standar ITU-T G.652 single mode, sambungan, konektor, dan splitter. Pada teknologi PON, splitter yang digunakan merupakan splitter pasif yang membagi daya keluaran sama rata serta tidak memerlukan sumber energi dari luar. Berdasarkan standar yang direkomendasikan oleh ITU-T G.984 passive splitter dapat membagi masukan menjadi maksimum 64 keluaran. Tabel 3 merupakan table dari loss passive splitter.

Tabel 3. Loss Splitter

\begin{tabular}{|l|l|}
\hline Jumlah Port & $\begin{array}{l}\text { Loss Splitter } \\
\text { (dB) }\end{array}$ \\
\hline 2 & $2,8-4,0$ \\
\hline 4 & 7.25 \\
\hline 8 & 10.38 \\
\hline 16 & 14.10 \\
\hline 32 & 17.45 \\
\hline 64 & 18 \\
\hline
\end{tabular}

\subsection{Optical Network Termination/Unit (ONT/ONU)}

ONT/ONU merupakan penyedia antarmuka jaringan ke layanan FTTx. ONU/ONT akan merubah sinyal optik yang ditransmisikan menjadi sinyal listrik untuk layanan FTTx. Perangkat ONU atau ONT memiliki sedikit perbedaan yaitu perangkat ONT dapat dihubungkan langsung ke perangkat user, sedangkat ONU memerlukan network terminal pada bagian user. 


\subsection{Power Link Budget (PLB) [12]}

Perhitungan unjuk kerja transmisi jaringan dilihat salah satunya dari nilai anggaran daya pada jaringan tersebut dengan mengetahui batasan redaman total yang diijinkan. Perhitungan ini menjamin daya yang dikirim oleh transmitter dapat diterima oleh receiver tidak kurang dari level daya minimum sesuai dengan parameter daya yang telah distandarisasi oleh ITU-T. Total redaman untuk link power budget dapat dihitung dengan menggunakan persamaan :

$\alpha_{\text {total }}=$ L. $\alpha_{\text {serat }}+N c \cdot \alpha_{c}+N s . \alpha_{s}+S p$

Perhitungan Margin Daya dihitung dengan persamaan :

$\mathrm{M}=(\mathrm{Pt}-\mathrm{Pr})-\alpha$ tot $-\mathrm{SM}$

Nilai daya yang diterima di ONT atau disisi pelanggan dihitung dengan persamaan :

$$
\text { PRx }=\text { PTx }-\alpha \text { tot }
$$

Dimana ;

$\alpha$ total : Redaman total sistem $(\mathrm{dB})$

$\mathrm{L} \quad$ : panjang total serat optik $(\mathrm{km})$

$\alpha_{\text {serat }}:$ Redaman serat optik ( $\left.\mathrm{dB} / \mathrm{Km}\right)$

$\alpha_{c} \quad:$ Redaman Konektor (dB/buah)

$\alpha_{s} \quad$ : Redaman sambungan ( $\mathrm{dB} /$ sambungan)

Nc : Jumlah konektor

Ns : Jumlah sambungan

Sp : Redaman Splitter (dB)

$\mathrm{Pt} \quad$ : Daya keluaran sumber optik $(\mathrm{dBm})$

$\operatorname{Pr} \quad$ : Sensitivitas daya maksimum detektor $(\mathrm{dBm})$

PRx : Daya terima, sensitivitas penerima $(\mathrm{dBm})$

PTx : Daya kirim (dBm)

M : Margin daya

SM : Safety Margin 6-8 dBm

\subsection{Rise Time Budget [12]}

Perhitungan rise time budget dipergunakan untuk sistem transmisi digital dalam menentukan batasan dispersi dari jaringan serat optik. Memperhitungkan nilai rise time budget dapat mempermudah untuk melihat unjuk kerja jaringan optik apakah telah memenuhi kapasitas kanal yang diinginkan. Nilai dari degradasi total waktu transisi dari link digital tidak melebihi $70 \%$ dari satu periode bit NRZ (Non-retum-to-zero) atau $35 \%$ dari satu periode bit untuk data RZ (return-tozero). Perhitungan rise time budget dapat dihitung dengan persamaan :

$$
T_{\text {total }}=\sqrt{\left(T \text { tx }^{2}+\text { T material }^{2}+T \text { intermodal }^{2}+T r x\right.}
$$

Dimana ;

Ttx $\quad$ : rise time pemancar (ns)

Trx $\quad$ : rise time penerima (ns)

Tintermodal : rise time dispersi intermodal

Tmaterial : rise time dispersi intramodal

Besarnya rise time dispersi material dapat dihitung dengan persamaan : 
Dimana ;

$\begin{array}{ll}\Delta \sigma & : \text { Lebar Spektral }(\mathrm{nm}) \\ \mathrm{L} & : \text { Panjang serat optik }(\mathrm{Km}) \\ \mathrm{Dm} & : \text { Dispersi Material }(\mathrm{ps} / \mathrm{nm} . \mathrm{Km})\end{array}$

Besarnya waktu batas (Tr) untuk pengkodean NRZ dan RZ :

$\operatorname{Tr}=\frac{0,7}{\text { Bitrate }} \quad($ Pengkodean NRZ)

$\operatorname{Tr}=\frac{0,35}{\text { Bitrate }} \quad($ Pengkodean NRZ $)$

\section{HASIL DAN PEMBAHASAN}

\subsection{Perancangan Jaringan FTTB dengan teknologi GEPON dan GPON}

Perancangan FTTB yang digunakan pada apartement $X$ di daerah Buah Batu menggunakan teknologi GEPON dan teknologi GPON. Penentuan jumlah dan jenis perangkat yang digunakan dipengaruhi oleh alokasi bandwidth yang telah diperhitungkan. Perhitungan alokasi bandwidth dalam perancangan jaringan FTTB merupakan faktor penting dalam menentukan Bill of quantity jaringan. Jumlah user dan jenis layanan merupakan data penting yang dibutuhkan dalam perhitungan untuk perancangan. Jumlah pelanggan didapatkan dari jumlah pelanggan/ homepass di apartemen tersebut. Berikut adalah tabel hasil survey lokasi pada apartemen X :

Tabel 4. Hasil Survei Lokasi

\begin{tabular}{|c|c|c|}
\hline Gedung & Kamar & Keterangan \\
\hline Lantai $1-3$ & Tidak ada kamar & Tempat parkir \\
\hline Lantai $4-7$ & Tidak ada kamar & Unit Bisnis \\
\hline Lantai $8-13$ & 10 kamar/lantai & Ruang Kamar \\
\hline Lantai 14 & 9 kamar & Ruang Kamar \\
\hline Lantai $15-25$ & 10 kamar/lantai & Ruang Kamar \\
\hline Lantai $26-27$ & 9 kamar/lantai & Ruang Kamar \\
\hline Lantai 28 & 10 kamar & Ruang Kamar \\
\hline Roof Top & - & - \\
\hline Total Pelanggan / Homepass & 207 & \\
\hline
\end{tabular}

Layanan yang dibutuhkan oleh pelanggan pada apartemen $\mathrm{X}$ adalah layanan triple play, yang terdiri dari telepon (voice), internet (data), dan televisi (video) dan CCTV . Layanan-layanan tersebut diberikan secara bundling dan yang digunakan pada perancangan ini adalah layanan bundling dengan bandwidth sebesar 16 Mbps. Total bandwidth yang diperlukan dalam perancangan ini adalah sebesar 3312 Mbps.

Tabel 5. Perhitungan jumlah Bandwidth

\begin{tabular}{|c|c|c|c|c|c|c|c|}
\hline \multirow{2}{*}{ No } & \multirow{2}{*}{$\begin{array}{c}\text { Jumlah } \\
\text { Homepass }\end{array}$} & \multicolumn{5}{|c|}{ Kebutuhan Bandwidth (Mbps) } & Total Bandwidth \\
\cline { 2 - 7 } & CCTV & IPTV & Data & VoIP & Reseave & (Mbps) \\
\hline 1 & 207 & 8 & 4 & 2 & $64(\mathrm{Kbps})$ & 1,36 & 16 \\
\hline \multicolumn{3}{|c|}{ Total ( Jml.Homepass $\mathbf{x}$ Bandwitdh ) } & 3312 \\
\hline
\end{tabular}


Pada perancangan ini OLT diletakkan di basement. Hal ini ditujukan agar ketika terjadi masalah pada ONT akan lebih mudah untuk menanganinya. Penempatan OLT di basement dapat menghemat biaya untuk maintenance perangkat. Pemilihan perangkat OLT harus disesuaikan dengan jarak dan banyaknya redaman yang dapat terjadi di sepanjang link. Pemilihan OLT harus mempertimbangkan besarnya nilai rise time yang dhasilkan sesuai dengan parameter standar rise time yang ditentukan. Pada perancangan link FTTB, OLT yang digunakan untuk GEPON adalah OLT Bell Alcatel Lucent 7360 isam fx 16 sedangkan OLT untuk GPON adalah OLT Alcatel Lucent 7432 ISAM FTTU , dengan perbandingan spesifikasi perangkat OLT dideskripsikan pada Tabel 6 :

Tabel 6. Perbandingan Spesifikasi OLT GEPON dan GPON

\begin{tabular}{|c|c|c|c|}
\hline \multirow{3}{*}{ Parameter } & GEPON & GPON & \multirow{3}{*}{ Unit } \\
\hline & $\begin{array}{c}\text { OLT Bell Alcatel Lucent } \\
7360 \text { isam fx } 16\end{array}$ & $\begin{array}{l}\text { OLT Alcatel Lucent } 7432 \\
\text { ISAM FTTU }\end{array}$ & \\
\hline & Spesifikasi GEPON & Spesifikasi GPON & \\
\hline Optical Transmit Power & $2-7$ & 5 & $\mathrm{dBm}$ \\
\hline Downlink Wavelength & 1490 & 1490 & $\mathrm{~nm}$ \\
\hline Uplink Wavelength & 1310 & 1310 & $\mathrm{~nm}$ \\
\hline Video Wavelength & 1550 & 1550 & $\mathrm{~nm}$ \\
\hline Spectrum Width & 1 & 1 & $\mathrm{~nm}$ \\
\hline Downstream Rate & 1.244 & 2.4 & Gbps \\
\hline Upstream Rate & 1.244 & 1.2 & Gbps \\
\hline Optical Rise Time & 150 & 150 & Ps \\
\hline Optical Fall Time & 150 & 150 & Ps \\
\hline Max.Work Temperature & 45 & 45 & ${ }^{\circ} \mathrm{C}$ \\
\hline Min.Work Temperature & -5 & -5 & ${ }^{\circ} \mathrm{C}$ \\
\hline Power Supply (DC) & 48 & -48 & V \\
\hline
\end{tabular}

Serat Optik yang digunakan adalah serat optik jenis single mode dengan spesifikasi serat rekomendasi ITU-T G.652.D. Spesifikasi serat G.652.D dapat dilihat pada tabel 7 [13]:

Tabel 7. Spesifikasi G.652D [13]

\begin{tabular}{|l|l|l|}
\hline Parameter & Spesifikasi & Unit \\
\hline Attenuation 1310 nm & $\leq 0,35$ & $\mathrm{~dB} / \mathrm{km}$ \\
\hline Attenuation 1490 nm & $\leq 0,28$ & $\mathrm{~dB} / \mathrm{km}$ \\
\hline Attenuation 1550 nm & $\leq 0,2$ & $\mathrm{~dB} / \mathrm{km}$ \\
\hline Allowable Bending Radius & $\geq 30$ & $\mathrm{Mm}$ \\
\hline $\begin{array}{l}\text { Chromatic Dispersion (1285- } \\
1330 \mathrm{~nm})\end{array}$ & $\leq 0,35$ & $\mathrm{~dB} / \mathrm{km}$ \\
\hline $\begin{array}{l}\text { Chromatic Dispersion (1550 } \\
\mathrm{nm})\end{array}$ & $\leq 0,18$ & $\mathrm{~dB} / \mathrm{km}$ \\
\hline
\end{tabular}

Serat jenis G.652.D digunakan dari OLT sampai ke ODC gedung sebagai serat feeder, dan dari ODC gedung ke ODP tiap lantai sebagai serat distribusi. Sedangkan serat G.657 digunakan sebagai serat drop, yaitu mulai dari ODP tiap lantai ke ruangan pelanggan atau ke perangkat penerima lainnya. Serat optik yang digunakan dari Optical Distribution Point (ODP) hingga ke ONT adalah jenis Single Core Per Tube (SCPT) denga jenis serat G.657. 
Tabel 8. Spesifikasi G.652D [14]

\begin{tabular}{|l|l|l|}
\hline Parameter & Spesifikasi & Unit \\
\hline Attenuation $1310 \mathrm{~nm}$ & $\leq 0,35$ & $\mathrm{~dB} / \mathrm{km}$ \\
\hline Attenuation $1550 \mathrm{~nm}$ & $\leq 0,28$ & $\mathrm{~dB} / \mathrm{km}$ \\
\hline Attenuation $11625 \mathrm{~nm}$ & $\leq 0,2$ & $\mathrm{~dB} / \mathrm{km}$ \\
\hline Allowable Bending Radius & $\geq 15$ & $\mathrm{~mm}$ \\
\hline
\end{tabular}

Jenis konektor yang digunakan adalah Subscriber Connector (SC) adalah SC 10/125 dengan nilai redaman sebesar $0.2 \mathrm{~dB} /$ buah. Konektor terdapat pada OLT, tepatnya penghubung antara frame input dan output pada ODF. Selain di OLT, konektor juga terdapat pada ODC dibagian input, ODP dibagian input, dan ONT di bagian input.

Passive splitter yang digunakan disesuaikan dengan jumlah homepass yang harus dipenuhi. Perancangan ini menggunakan 2 jenis passive splitter dengan dua tingkat. Pada jaringan FTTB menggunakan GEPON, passive splitter yang digunakan menggunakan dua tingkat yaitu rasio 1:4 sebanyak 4 buah dan rasio 1:16 sebanyak 14 buah. Sedangkan pada jaringan FTTB dengan teknologi GPON jumlah passive splitter yang digunakan dalam perancangan ini adalah 20 buah untuk rasio 1:8 dan 20 buah untuk rasio 1:16. Berdasarkan perhitungan spesifikasi diatas, maka gambar 2 merupakan konfigurasi jaringan FTTB menggunakan GEPON dengan 2 tingkat passive splitter :

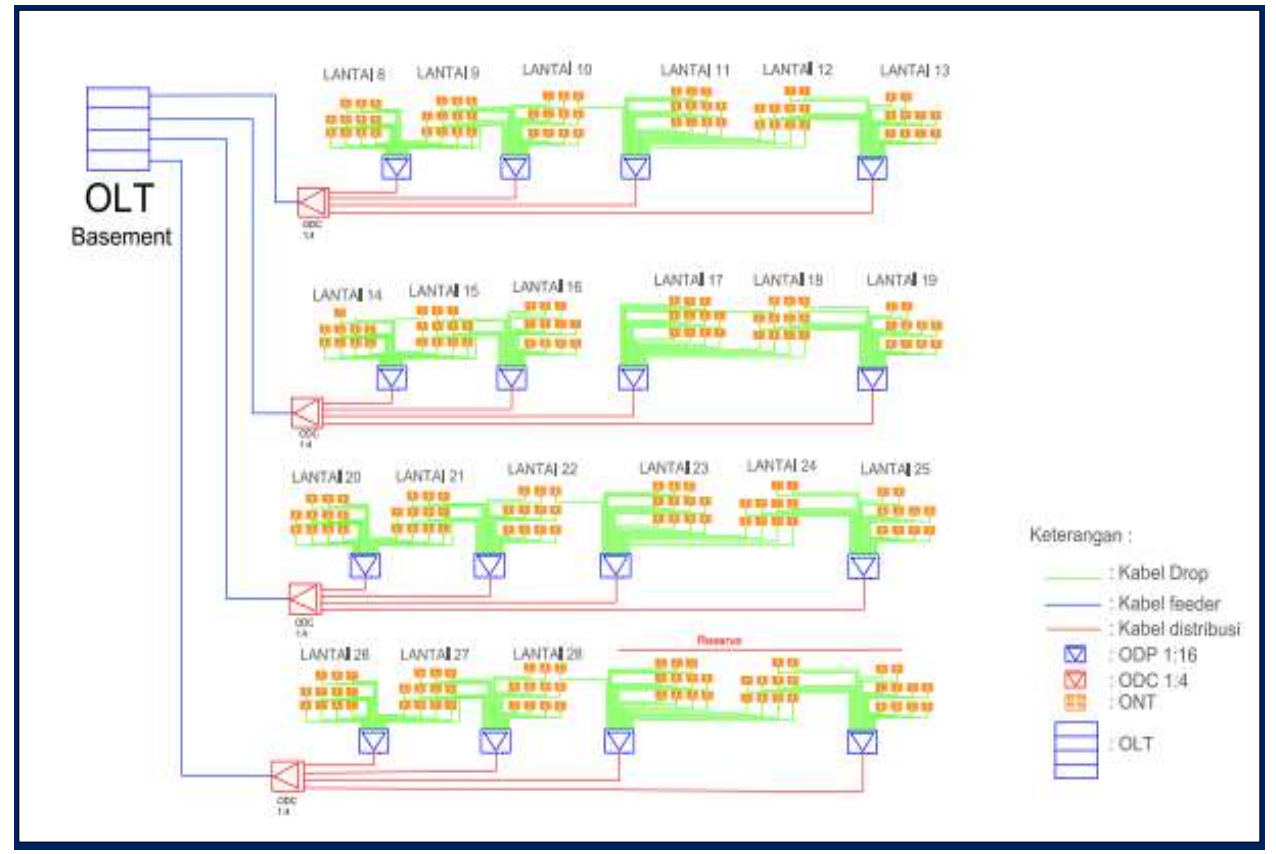

Gambar 2. Konfigurasi Jaringan FTTB GEPON

Tabel 9. Perbandingan Kebutuhan Perangkat FTTB GEPON dan GPON

\begin{tabular}{|c|c|c|c|}
\hline \multirow{2}{*}{ Perangkat } & GEPON & GPON & \multirow{2}{*}{ Unit } \\
\cline { 2 - 3 } & Jumlah & Jumlah & \\
\hline OLT & 4 & 2 & Buah \\
\hline ONT & 240 & 207 & Buah \\
\hline ODP & 14 & 19 & Buah \\
\hline PS 1:4 & 4 & & Buah \\
\hline PS 1: & 14 & 20 & Buah \\
\hline PS 1:16 & & 20 & Buah \\
\hline Kabel Feeder G.652.D & 100 & 200 & M \\
\hline Kabel Distribusi ( Serat G.652.D ) & 3 & 3.6 & Km \\
\hline Kabel Drop ( Serat G.652.D) & 3 & 3.8 & Km \\
\hline
\end{tabular}




\subsection{Link Power Budget}

Tabel 10.Perbandingan nilai Link Power Budget GEPON dan GPON

\begin{tabular}{|c|c|c|c|c|c|c|c|c|c|}
\hline \multirow[b]{3}{*}{$\begin{array}{c}\text { Uraia } \\
\mathbf{n}\end{array}$} & \multirow[b]{3}{*}{$\begin{array}{c}\text { Satua } \\
\mathbf{n}\end{array}$} & \multicolumn{4}{|c|}{ GEPON } & \multicolumn{4}{|c|}{ GPON } \\
\hline & & \multicolumn{2}{|c|}{ Jarak Terjauh } & \multicolumn{2}{|c|}{ Jarak terdekat } & \multicolumn{2}{|c|}{ Jarak Terjauh } & \multicolumn{2}{|c|}{ Jarak terdekat } \\
\hline & & $\begin{array}{c}\text { Dow } \\
\text { n } \\
\text { strea } \\
\text { m }\end{array}$ & $\begin{array}{c}\text { Upstrea } \\
\text { m }\end{array}$ & $\begin{array}{c}\text { Down } \\
\text { strea } \\
\text { m }\end{array}$ & $\begin{array}{c}\text { Upstrea } \\
\text { m }\end{array}$ & $\begin{array}{c}\text { Down } \\
\text { strea } \\
\text { m }\end{array}$ & $\begin{array}{c}\text { Upstrea } \\
\text { m }\end{array}$ & $\begin{array}{c}\text { Down } \\
\text { stream }\end{array}$ & $\begin{array}{c}\text { Upstrea } \\
\text { m }\end{array}$ \\
\hline Jarak & $\mathrm{Km}$ & 0.8 & 0.8 & 0.1 & 0.1 & 0.8 & 0.8 & 0.1 & 0.1 \\
\hline$\alpha$ total & $\mathrm{Db}$ & 22.81 & 4.79 & 22.67 & 4.65 & 25.94 & 4.91 & 25.80 & 4.77 \\
\hline PRx & $\mathrm{DBm}$ & $\begin{array}{c}- \\
25.81\end{array}$ & -7.79 & -25.67 & -7.65 & -26.94 & -5.91 & -26.80 & -5.77 \\
\hline $\mathbf{M}$ & $\mathrm{dB}$ & 2.19 & 20.21 & 2.33 & 20.35 & 1.06 & 22.09 & 1.20 & 22.23 \\
\hline
\end{tabular}

Perhitungan anggaran daya untuk FTTB digunakan untuk mengetahui besar nilai redaman total. Besarnya daya sensitivitas yang diperbolehkan berdasarkan standar GEPON dan GPON adalah $-28 \mathrm{dBm}$. Perhitungan anggaran daya akan dibagi menjadi dua perhitungan yaitu arah downstream dan arah upstream. Perhitungan akan dilakukan dengan pendekatan homepass yang memiliki jarak terdekat dan homepass yang memiliki jarak terjauh. Persamaan untuk perhitungan link power budget menggunakan persamaan 1. Perancangan FTTB - GEPON dan GPON jarak homepass yang terjauh berada di $\mathrm{ONT}_{207}$ sedangkan jarak homepass yang terdekat berada di $\mathrm{ONT}_{1}$. Berdasarkan persamaan 1,2,dan 3 akan didapatkan perbandingan nilai redaman total, daya terima dan margin daya yang ditunjukkan pada tabel 10 :

Pada Tabel 10, arah downstream maupun upstream di link FTTB - GEPON dan link FTTB- GPON untuk jarak terjauh maupun terdekat didapatkan nilai redaman masih dibawah nilai redaman maksimal menurut standar ITU.T yaitu sebesar $28 \mathrm{~dB}$ sehingga link ini masih memenuhi syarat dari sisi nilai redaman total. Pada jarak terdekat ataupun terjauh, nilai daya PRx yang didapatkan dari perhitungan kedua link GEPON dan GPON arah downstream maupun upstream didapatkan bahwa nilainya masih memenuhi syarat dari sisi nilai minimum daya terima dari standar ITU sebesar $-28 \mathrm{dBm}$. Nilai Margin (M) yang didapatkan dari tabel perhitungan diatas untuk GEPON maupun GPON masih berada di atas 0 ( nol ). Berdasarkan hasil tersebut maka link downstream maupun upstream pada kedua teknologi tersebut masih memenuhi kelayakan link power budget.

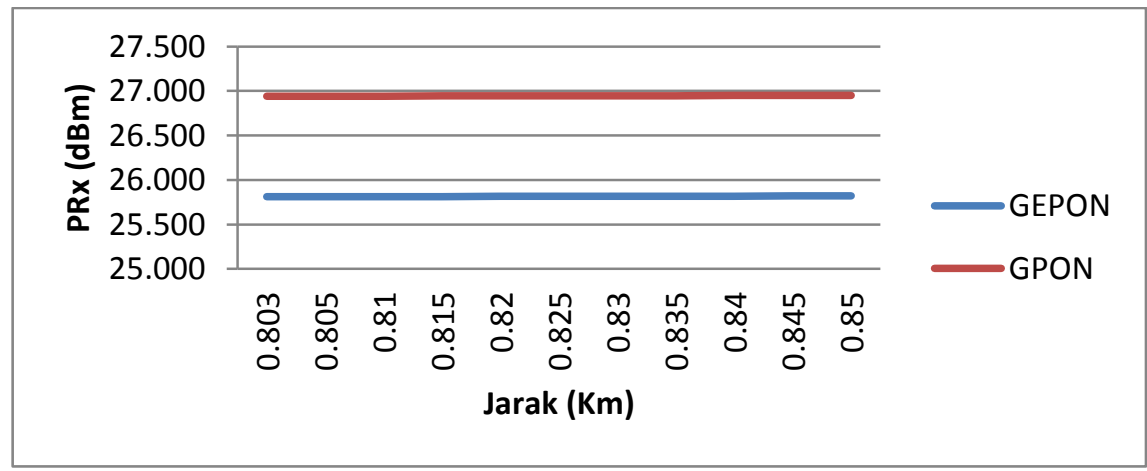

Gambar 3. Perbandingan Daya Terima GEPON - GPON Arah Downstream 
Gambar 3 menyatakan perbandingan besarnya daya terima (PRx) pada teknologi GEPON dan GPON. Perbandingan daya terima pada link GEPON dan link GPON pada jaringan FTTB sangat dipengaruhi oleh jarak antara OLT dan ONT. Semakin besar jaraknya maka semakin besar daya terimanya. Hasil perbandingan menunjukkan bahwa daya terima pada GPON lebih besar dibandingkan GEPON.

\subsection{Rise Time Budget}

Pada link GEPON dan GPON, besarnya nilai rise time menggunakan persamaan 4 sehingga didapatkan nilai rise time pada tabel berikut ini :

Tabel 11. Perbandingan nilai Rise Time Budget GEPON dan GPON

\begin{tabular}{|l|c|c|c|c|}
\hline \multirow{2}{*}{} & \multicolumn{2}{|c|}{ GEPON } & \multicolumn{2}{c|}{ GPON } \\
\cline { 2 - 5 } & Upstream & Downstream & Upstream & Downstream \\
\hline Jarak & $0.3 \mathrm{~km}$ & $0.3 \mathrm{~km}$ & $1 \mathrm{~km}$ & $1 \mathrm{~km}$ \\
\hline $\operatorname{Tr}(\mathrm{NRZ})$ & $0,5627 \mathrm{~ns}$ & $0,5627 \mathrm{~ns}$ & $0,5627 \mathrm{~ns}$ & $0,2814 \mathrm{~ns}$ \\
\hline $\operatorname{Tr}(\mathrm{RZ})$ & $0,2804 \mathrm{~ns}$ & $0,2804 \mathrm{~ns}$ & $0,2814 \mathrm{~ns}$ & $0,1407 \mathrm{~ns}$ \\
\hline T total & $0,2061 \mathrm{~ns}$ & $0,2506 \mathrm{~ns}$ & $0,260 \mathrm{~ns}$ & $0.25 \mathrm{~ns}$ \\
\hline
\end{tabular}

Pada tabel diatas untuk arah upstream link GEPON nilai rise time didapatkan sebesar 0.2061 berada dibawah batas nilai waktu pengkodean NRZ sebesar 0.5627 dan RZ sebesar 0.2804. Pada link GPON arah upstream nilai rise time sebesar 0.260 juga menunjukkan nilai berada dibawah nilai standar waktu pengkodean NRZ sebesar 0.5627 dan RZ sebesar 0.2814. Hasil dari kedua nilai rise time baik downstream maupun upstream tersebut menunjukkan nilai rise time link system terpenuhi sesuai dengan standar.

\subsection{Analisis BER ( Bit Error Rate )}

Perhitungan Bit Error Rate kedua link GEPON dan GPON disimulasikan menggunakan sebuah software OptiSystem dengan nilai seluruh elemen perangkat disesuaikan dengan perangkat asli sehingga diharapkan nilai yang didapatkan mendekati nilai real. Simulasi yang dibuat adalah simulasi arah downstream dan upstream berdasarkan jarak terjauh dengan spesifikasi perangkat yang telah dijelaskan sebelumnya.

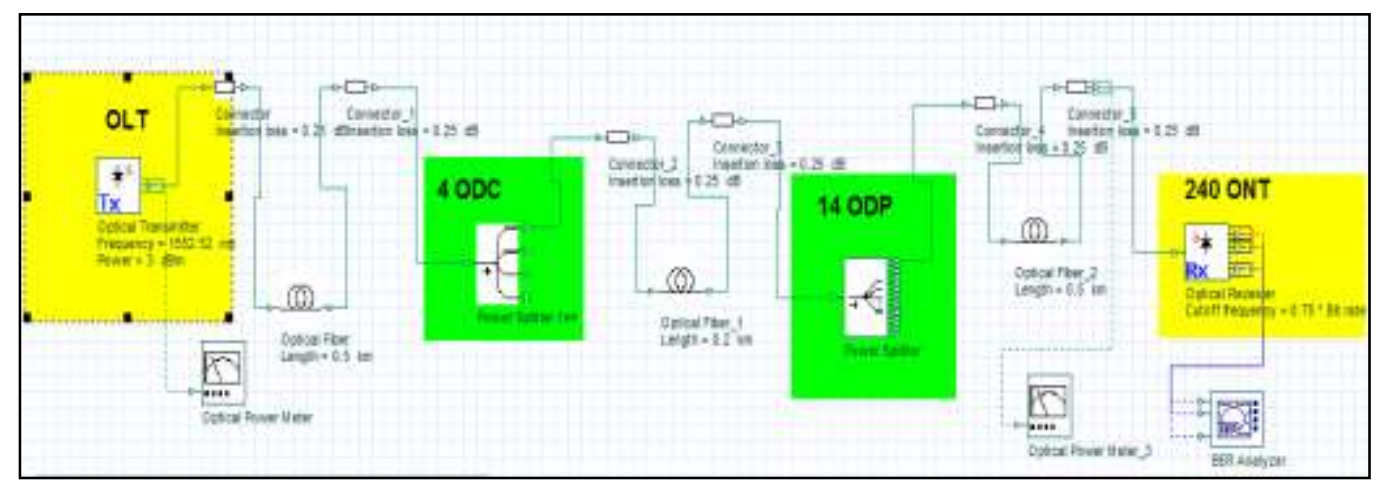

Gambar 4. Simulasi ONT terjauh Dowstream link GEPON 


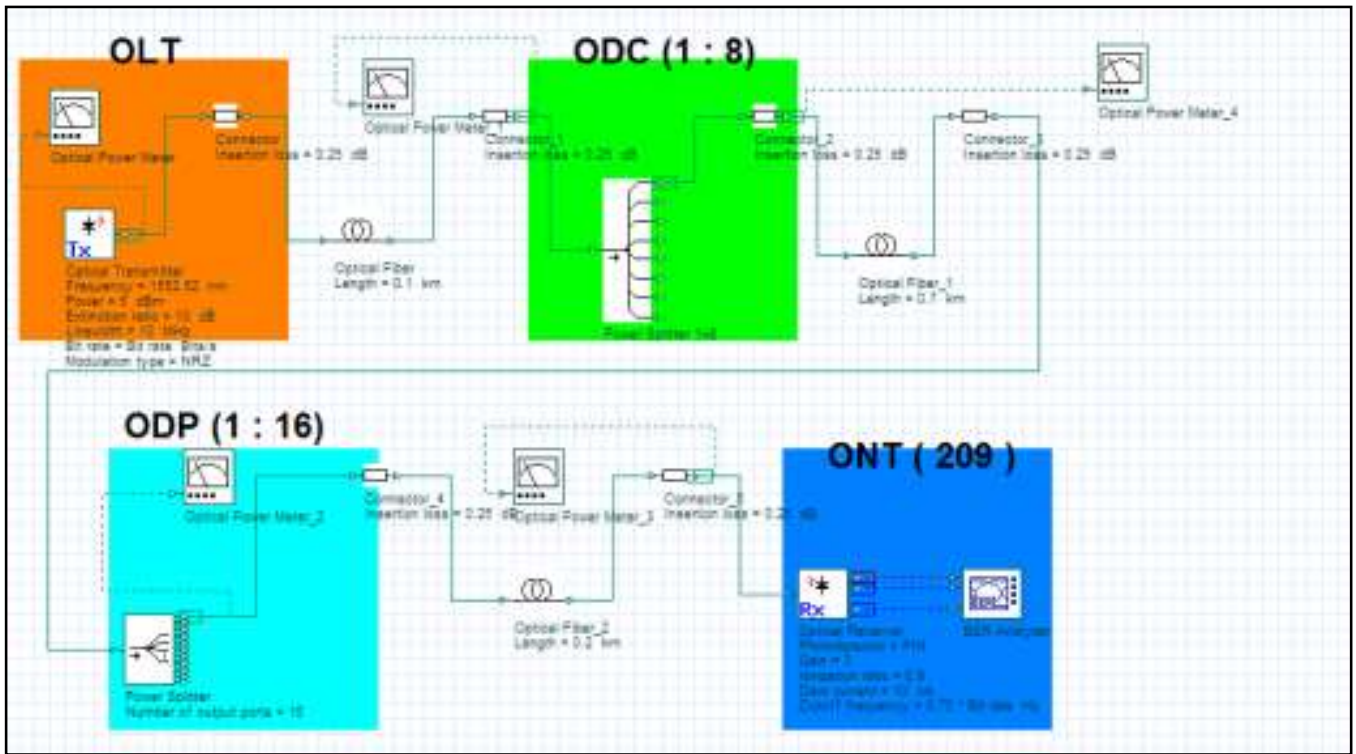

Gambar 5. Simulasi ONT terjauh Dowstream link GPON

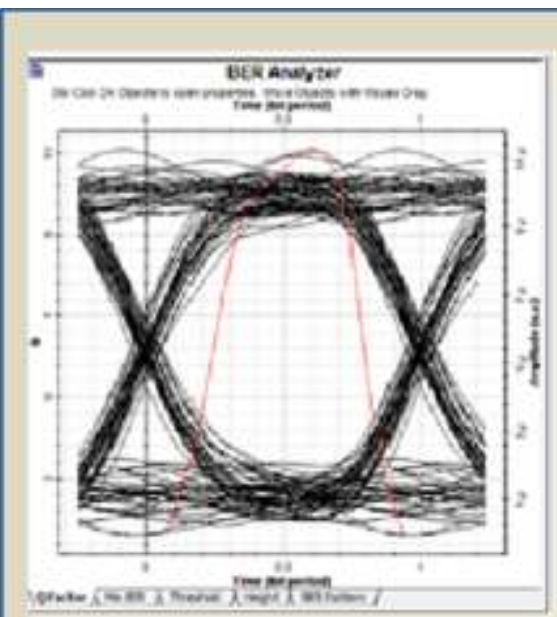

(a). GEPON

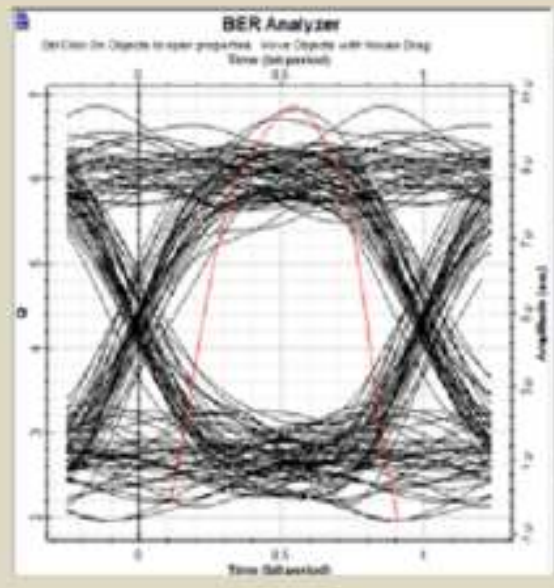

(b). GPON

Gambar 6. Nilai BER Downstream

Berdasarkan hasil perancangan didapatkan nilai Bit Error Rate (BER) arah downstream untuk link GEPON sebesar 7x 10 ${ }^{-29}$, sedangkan untuk link GPON nilai BER sebesar $3.62955 \times 10^{-12}$ . Nilai tersebut lebih kecil dari nilai BER ideal sistem komunikasi serat optik yaitu bernilai $10^{-9}$.

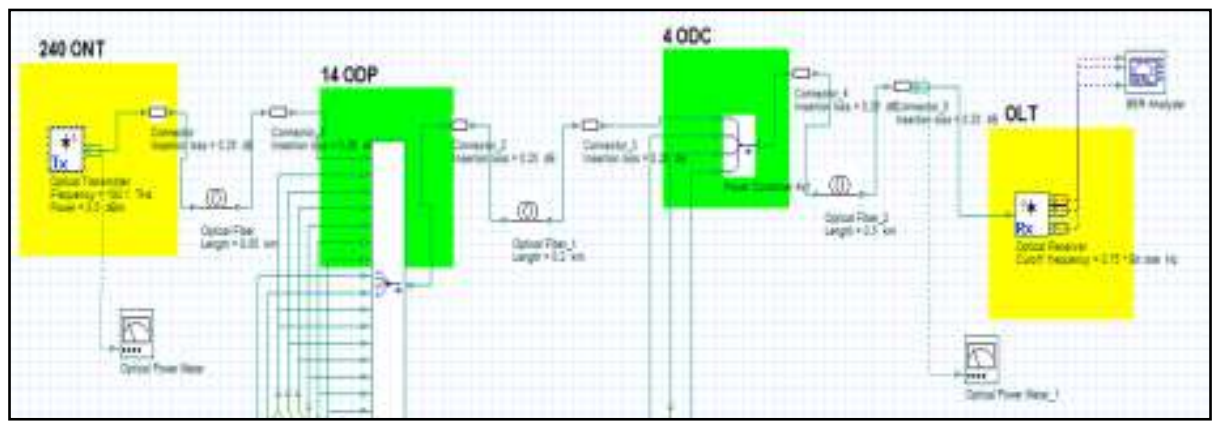

Gambar 7. Simulasi ONT terjauh Upstream link GEPON 


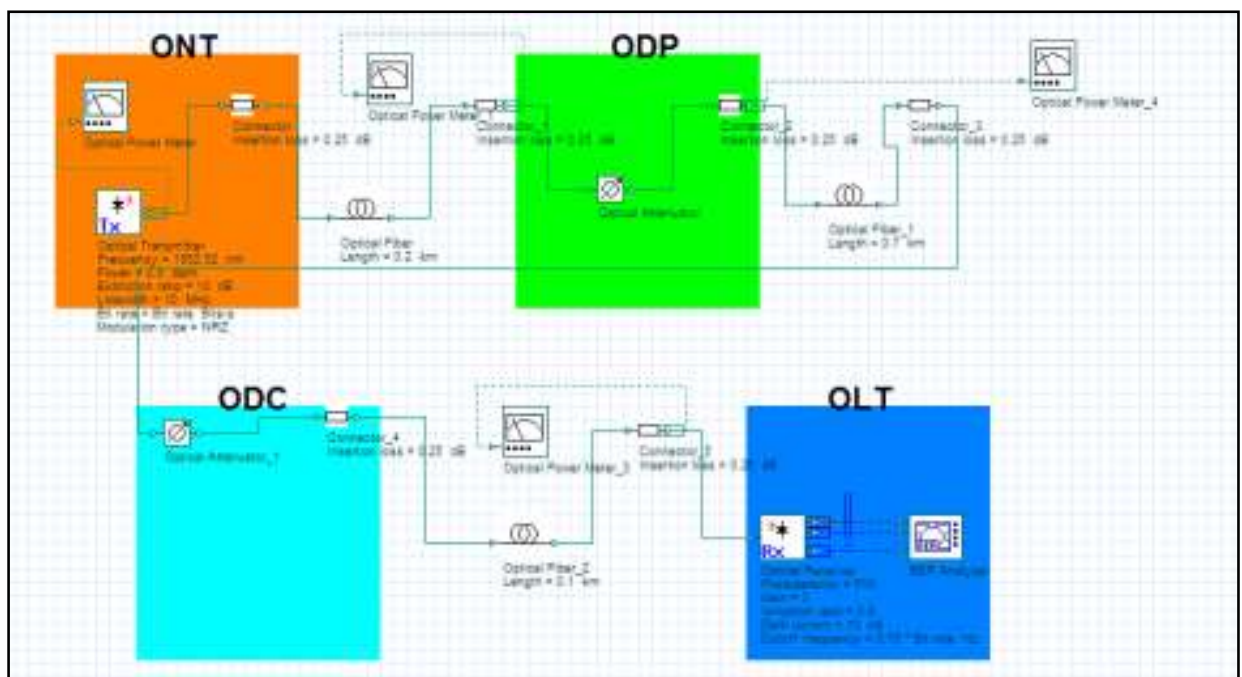

Gambar 8. Simulasi ONT terjauh Upstream link GPON

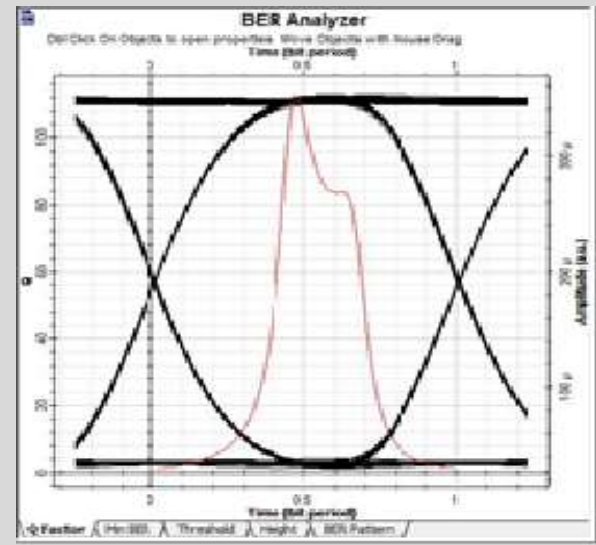

(a). GEPON

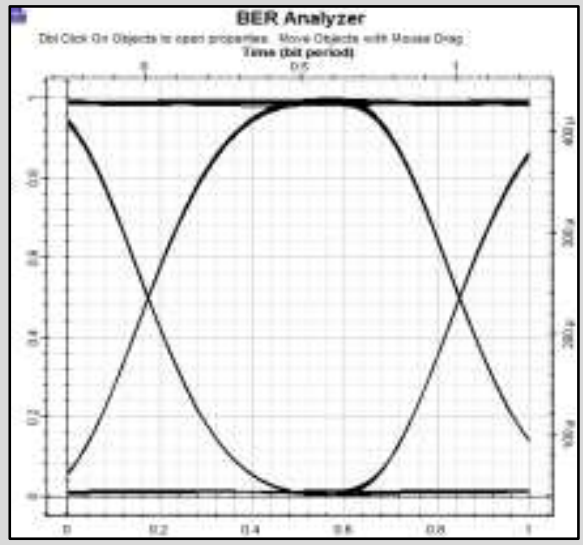

(b). GPON

Gambar 9. Nilai BER Upstream

Berdasarkan hasil simulasi BER pada arah upstream, didapatkan nilai BER untuk link GEPON maupun link GPON adalah $\approx 0$ dan nilai tersebut sangat baik karena masih diatas nilai maksimum yaitu $10^{-9}$ sehingga konfigurasi upstream dapat dikatakan sangat baik.

\section{KESIMPULAN}

Berdasarkan hasil perhitungan dan simulasi dari perancangan jaringan FTTB didapatkan kesimpulan bahwa:

1. Besarnya nilai redaman untuk link GEPON terjauh sebesar $22.81 \mathrm{~dB}$ arah downstream dan $4.79 \mathrm{~dB}$ arah upstream sedangkan untuk link terdekat sebesar $22.67 \mathrm{~dB}$ arah downstream dan $4.65 \mathrm{~dB}$ arah upstream. Pada teknologi GPON nilai redaman terjauh sebesar $25.94 \mathrm{~dB}$ arah downstream dan $4.91 \mathrm{~dB}$ arah upstream sedangkan untuk link terdekat sebesar 25.80 $\mathrm{dB}$ arah downstream dan $4.77 \mathrm{~dB}$ arah upstream. Berdasarkan nilai tersebut maka nilainya masih memenuhi syarat dari sisi nilai minimum daya terima dari standar ITU sebesar -28 $\mathrm{dBm}$. 
2. Besarnya nilai rise time untuk arah upstream link GEPON nilai rise time didapatkan sebesar 0.2061 berada dibawah batas nilai waktu pengkodean NRZ sebesar 0.5627 dan RZ sebesar 0.2804. Pada link GPON arah upstream nilai rise time sebesar 0.260 juga menunjukkan nilai berada dibawah nilai standar waktu pengkodean NRZ sebesar 0.5627 dan RZ sebesar 0.2814.

3. Nilai BER untuk link GEPON sebesar $7 \times 10^{-29}$ arah downstream dan mendekati nol (0) untuk arah upstream. Sedangkan nilai BER untuk link GPON sebesar $3.62955 \times 10^{-12}$ arah downstream dan BER bernilai $\approx 0$ untuk arah upstream. Kedua nilai menunjukkan bahwa konfigurasi downstream maupun upstream untuk jaringan FTTB memiliki kualitas transmisi yang baik.

\section{DAFTAR PUSTAKA}

[1] Lambert, S., Montalvo J., Jose A. Torrijos, Lannoo B., Colle D., dan Pickavet, M. 2013. Energy demand of high-speed connectivity services in NG-PON massive deployments. Optical Communication (ECOC 2013) 39th European Conference and Exhibition 2013.

[2] Kocher, D., Kaler, R.S., dan Randhawa, R. 2013. 50 km bidirectional FTTH transmission comparing different PON standards. International journal for light and electron optics, vol. 124, no.21, pp.5075- 5078.

[3] FTTH Handbook edition 5. 2012

[4] Kaler, R., Teotia, P., Kaler R.S. 2011. Simulation of FTTH at 10 Gbit/s for 8 OUT by GE-PON Architecture. Optik122 pp.1985 -1989.

[5] Kocher, D., Kaler R.S., Randhawa, R. 2013. Simulation of fiber to the home triple play services at 2 Gbit/s using GEPON architecture for 56 ONUs. Optik 124 pp : 5007-5010.

[6] Sumanpreet and Sanjeev, D. 2015. Performance Analysis of Gigabit Passive Optical Network Using 2Gbit/Sec Downstream Transmission. International Journal of Advanced Research in Electrical, Electronics and Instrumentation Engineering, Vol.4, pp 743 - 748.

[7] Pawel, P.dkk.2012. FTTB+LAN: a Flexible Access Architecture for Residential and Business Users. FedCSIS multiconference. September 2012.

[8] Gupta, M., Malhotra, N. dan Pathak, A. N.. 2010. Performance Analysis of FTTH at 10 Gbit/s by GEPON Architecture. (IJCSI), vol. 7, no. 5, pp. 268-271.

[9] Parkash, S., Kumar, D., Sharma, A., dan Malhotra, R. 2014. Performance Investigation of GEPON Fiber To The Home Network Under Varying Data Rates and Users. International Multi Track Conference (IMTC), vol. 1, pp. 156-159.

[10] Jay, S., Neumann, K. H. dan Plückebaum, T. 2013. Comparing FTTH access networks based on P2P and PMP fibre topologies. Telecommunications Policy: Elsevier B.V. 2013. http://dx.doi.org/10.1016/j.telpol.2013.04.010i.

[11] ITU-T Recommendation G.984.1.2003. Gigabit-capable Passive Optical Networks (GPON) GeneraL Characteristics.

[12] Keiser, G. 2010. Optical Fiber Communications, 4th ed. New York:McGrawHill.

[13] ITU-T Recommendation G.652..2009. Characteristics of a single mode optical fibre and cable.

[14] ITU-T Recommendation G.657..2009. Characteristics of a bending loss insensitive single mode optical fibre and cable for the access network. 